\author{
Renata Matysik-Pejas \\ University of Agriculture in Krakow \\ e-mail: rrmatysi@cyf-kr.edu.pl \\ ORCID: 0000-0003-3485-0970
}

\title{
SELECTED DETERMINANTS OF PRODUCTION AND SALES OF PRODUCTS IN SHORT FOOD SUPPLY CHAINS BY FARMS KEEPING ANIMALS OF NATIVE BREEDS*
}

DOI: $10.15611 /$ pn.2020.8.08

JEL Classification: Q01, Q13, Q18

(C) 2020 Renata Matysik-Pejas

This work is licensed under the Creative Commons Attribution-ShareAlike 4.0 International License. To view a copy of this license, visit http://creativecommons.org/licenses/by-sa/4.0/

Quote as: Matysik-Pejas, R. (2020). Selected determinants of production and sales of products in short food supply chains by farms keeping animals of native breeds. Prace Naukowe Uniwersytetu Ekonomicznego we Wrocławiu, 64(8).

\begin{abstract}
The aim of the study was to identify factors determining farms' decision to produce and sell products obtained from animals of native breeds in short food supply chains. The empirical material was the result of a survey carried out in 2017. The direct interview method was used to collect information. The research sample included 144 farms keeping animals of native breeds of cattle, sheep and pigs. The spatial scope of the research covered three provinces of south-eastern Poland. The group of factors positively stimulating the development of food sales in short supply chains includes the knowledge and skills of breeders and the expected demand for products from the farms. In turn, the group of factors constituting obstacles and causing farms not to undertake this activity is connected with the necessary amount of work input, the need to develop a marketing concept for this activity and to create an appropriate image on the market, as well as veterinary, sanitary and tax regulations.
\end{abstract}

Keywords: short food supply chains, food of animal origin, native breeds.

* Publication made within the framework of the project "Directions of use and the protection of farm animal genetic resources in sustainable development conditions" co-financed by the National Center for Research and Development as part of the Strategic Programme of Scientific Research and Development Works "Environment, Agriculture and Forestry" - BIOSTRATEG, Contract No. BIOSTRATEG2/297267/14/NCBR/2016. 


\section{Introduction}

In recent years, changes taking place in the food supply chain are becoming increasingly noticeable, leading to the creation of new connections between producers and consumers and the return (at least in part) to local agricultural production and local food processing (Official Journal of the European Union, 2018, p. 22). Local food production is a part of the sustainable food systems and the sustainable development of rural areas (Michalczyk, 2017; Mount, 2012;). Therefore these changes are supported by the European Union, which within the framework of rural development policy, recommends the creation of short food supply chains as alternative to conventional (industrial) chains. In accordance with the Regulation of the European Parliament and of the Council (EU) no 1305/2013 of 17 December 2013, short supply chains include a limited number of business entities involved in cooperation, bring local economic development and are characterized by close geographical and social ties between market participants. These connections are the basis for building trust between producers (farmers), processors and consumers (Aguiar, DelGrossi, and Thomé 2018, p. 4; Gołębiewski, 2019). In other words, short food supply chains are forms of organized systems of the production, processing, distribution and sale of food, which minimize the number of intermediaries between the producers and the buyers (Elghannam, Mesias, Escribano, Fouad, Horrillo, and Escribano, 2019, p. 2; Serafin, 2018, p. 4).

The experiences of many countries show that short supply chains are becoming more and more popular and bring benefits, especially for smaller farmers (Marketing sustainable agriculture... 1998; Short food supply chains in Europe's South, 2018a; Short food supply chains in Europe's North, 2018b). Short food supply chains offer additional sales opportunities for food produced on the farm. This reduces their dependence on strong players in the supply chain and increases their ability to participate directly in the local food market (Galli and Brunori, 2013). In addition, processing food on the farm is associated with the creation of added value. The value of farm products can be increased in different ways, for example by chilling, smoking, processing, packaging, labeling, distributing etc. (Born and Bachmann, 2006 , p. 1). Hence farmers can increase the value of offered products and at the same time have a greater impact on their prices (Kania and Musiał, 2017, p. 106). This guarantees that most of the income from the sales of the produced food will remain on the farm. The direct participation in the local food market allows farms to take over the margin, which, under the conditions of conventional food channels, goes into the hands of intermediaries (Michalczyk, 2018, p. 229). Moreover, operating in short supply chains allows small and medium-sized farms to survive more difficult economic periods (La Trobe, 2001) because they are less sensitive to market risks, especially when combined with longer chains (Kneafsey, Venn, Schmutz, Balázs, Trenchard, Eyden-Wood, Bos, Sutton, and Blackett, 2013, p. 17). 
Short food supply chains also support the growth of local and regional economies. Selling food at its place of origin has a multiplier effect, which is an implication of consumer demand, under the influence of which various other business activities are developed (Herda-Kopańska, 2017; Pinchot, 2014, p. 11). This allows to keep more money in the local economy, and leads to creation of new jobs (Peters, 2012, p. 15). The functioning of short supply chains in certain areas also favours the strengthening of local social ties. Short supply chains are an impulse to activate local potential and factor in improving the image of little-known and neglected regions. Their importance may be particularly evident in geographically disadvantaged areas (Official Journal of the European Union, 2011, p. 3).

Currently the law in Poland facilitates the sales of food in short supply chains. This also concerns farms with livestock production. Farmers who want to offer products of animal origin can introduce them legally to the market through direct sale, marginal, local and limited activities (MLO) and agricultural retail trade (RHD). The listed activities differ in the type of offered products and scope of activity and are subject to the supervision of the Veterinary Inspection.

Direct participation in the market with good quality products can be an attractive alternative to farms keeping animals of native breeds. These breeds are characterized by lower productivity, which results in lower profitability of animal husbandry compared to breeds used in intensive production. This is one of the reasons why farmers can apply for subsidies implemented within the framework of the agrienvironmental package "Conservation of endangered animal genetic resources in agriculture" financed from the Rural Development Programme 2014-2020. Besides the support which makes breeding profitable, these activities are primarily aimed at preserving biodiversity and saving genetic reserves. The protection of native breeds is very important because of the role they played in the development history of their regions of origin. These breeds are a reference point for local traditions associated with the production of food. They also play an important role in protecting the local cultural heritage. Moreover, they contribute significantly to the preservation of typical rural landscapes, historically associated with certain breeds (Barłowska, 2011, p. 4; Krupiński, 2012, p. 6).

\section{Research material and methods}

The main aim of this study was to identify the factors determining decision of farms to produce and sell products obtained from animals of native breeds in short food supply chains. The empirical material was the result of a survey carried out in 2017. The direct interview method was used to collect information. The research sample included 144 farms that are beneficiaries of the Program for the Protection of Genetic Resources of Farm Animals. Animals of native breeds of cattle, sheep and pigs were kept on the surveyed farms (Table 1). The spatial scope of the research covered three provinces of south-eastern Poland, i.e. Małopolskie, Lubelskie and Podkarpackie 
(Table1). These provinces were selected for the research due to the specificity of local agriculture, which is conducive to keeping animals of native breeds.

Table 1. Structure of the surveyed farms according to the species of animals kept on the farm and location, $N=144$

\begin{tabular}{|l|c|l|c|}
\hline \multicolumn{1}{|c|}{ Animal species } & Structure (\%) & \multicolumn{1}{c|}{ Province } & Structure (\%) \\
\hline Cattle & 35.4 & Lubelskie & 36.1 \\
\hline Sheep & 51.4 & Małopolskie & 32.6 \\
\hline Pigs & 13.2 & Podkarpackie & 31.3 \\
\hline
\end{tabular}

Source: own research.

For the analysis of empirical data, structure indicators and the chi square independence test $\left(\chi^{2}\right)$ were used. This test examines the relationship between the variables measured on a nominal scale. The chi square independence test $\left(\chi^{2}\right)$ is based on comparing the values obtained in the study (observed) and expected (theoretical) values on the assumption that there is no relationship between the variables:

$$
\chi^{2}=\sum_{\mathrm{i}=1}^{\mathrm{k}} \sum_{\mathrm{j}=1}^{\mathrm{k}} \frac{\left(n_{i j}-\hat{n}_{i j}\right)^{2}}{\hat{n}_{i j}},
$$

where: $n_{i j}$ - observed values, $\hat{n}_{i j}$ - theoretical values.

It tests the $\mathrm{H}_{0}$ hypothesis assuming that the researched variables are independent of the alternative $\mathrm{H}_{1}$ hypothesis concerning their relationship. The test statistic, assuming the truthfulness of $\mathrm{H}_{0}$, has a $\chi^{2}$ distribution of $(k-1) \cdot(n-1)$ degrees of freedom $(d f)$. For the conducted analyses, the significance level $(p)$ of 0.05 was assumed.

\section{Research results}

The placing on the market of food of animal origin by farms requires, first of all, to start the business of direct sales, marginal, local and limited activities (MLO) or agricultural retail trade (RHD). It is a necessary condition that these actors could create short food supply chains. The functioning of farms as direct participants of market trade is connected with the extension of their activities to the issues of raw material processing, sales and activities related to sales. These are not easy decisions nor made on a massive scale by farms, because they require solving many problems of a production, technological, organizational, sanitary or marketing nature and are associated with a significant time commitment of farmers and their families.

Among the surveyed farms, the production and sale of products in short food supply chains obtained from animals of native breeds were carried out on a small scale. Only $17.4 \%$ of farm owners confirmed that they conduct direct sales. The other 
activities were of a secondary nature, because agricultural retail trade was declared by $3.5 \%$, and marginal, local and limited activity only by $2.1 \%$ of farm owners.

Many different reasons may determine the start of business related to the sale of food in short supply chains by farms. In the opinion of nearly $70 \%$ of farm owners, their knowledge and skills are factors that could positively influence the transition from the production of raw material to the next stage, which is manufacturing products and offering them directly to consumers. On the other hand, $9 \%$ of the breeders were of the contrary opinion, and $21.5 \%$ consider knowledge and skills as irrelevant factors (Figure 1). The verification of the results using the $\chi^{2}$ independence test showed the existence of differences in the perception of this factor by the surveyed farmers depending on the animal species kept on the farm $\left(\chi^{2}=23.939\right.$, $p=0.000$ ), see Table 2 . In this case $86.3 \%$ of cattle breeders and $84.2 \%$ of pig breeders found this factor positive, while in the case of sheep breeders this rate was about $54 \%$ and at the same time over $32 \%$ of sheep farmers indicated knowledge and skills as a neutral factor. Farmers' knowledge and skills are the necessary resources for the proper management of the farm because the owner performs both executive and managerial functions. The modern farmer must have the technological knowledge of animal (and plant) production, technical knowledge as well as knowledge about the functioning of the farm in the market environment, which is essential for making the right decisions (Derehajło, 2018; Urban, 2008). The knowledge and skills of the owners allow for the creative use of other resources possessed by farms.

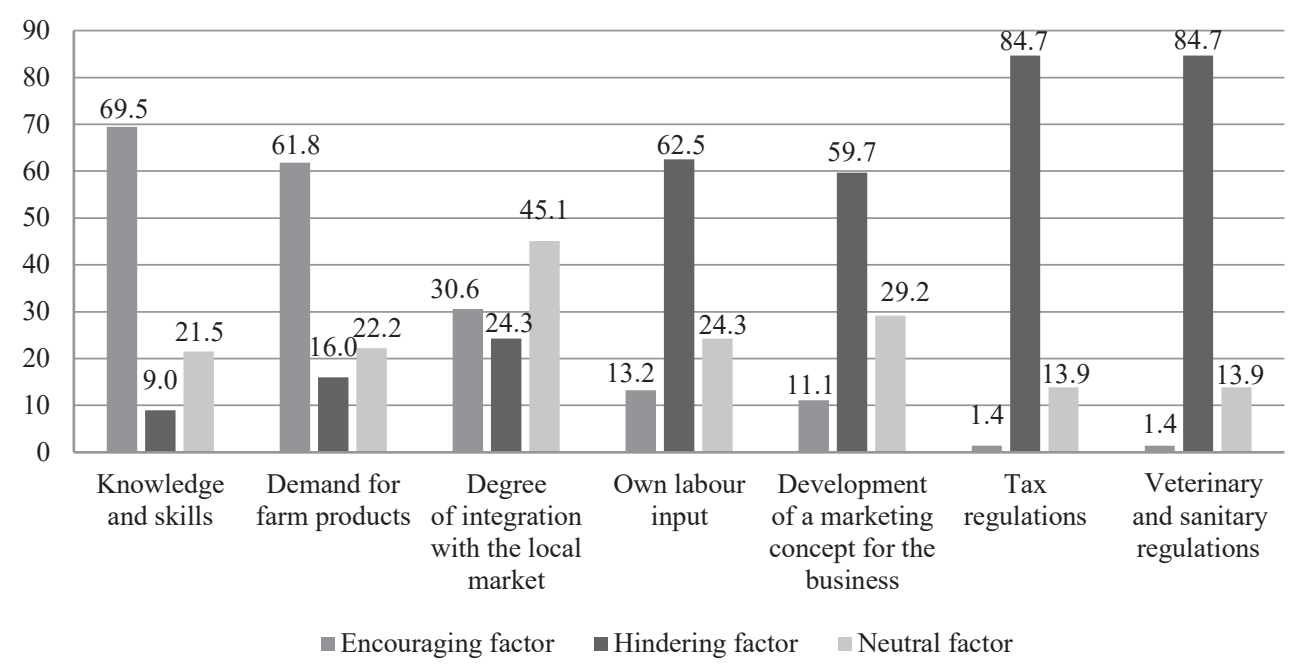

Fig. 1. Perception of factors determining the production and sale of products obtained from animals of native breeds by farms in short food supply chains (\%), $N=144$

Source: own research. 
Farm owners that want to sell products of animal origin directly to consumers need to know if their products will find buyers. Therefore, one of the significant factors in the market environment of farms is the level of demand for the offered products. The needs of the group of customers to whom the offered range will be addressed is the main determinant for undertaking and the development of food sales in short supply chains. Meeting the demand of potential consumers is facilitated by the location of farms in the vicinity of large urban centres (Sroka, Wojewodzic, and Pölling 2016), which is regarded as one of the main success factors of such activities. In the case of the surveyed sample, nearly $62 \%$ of the farmers confirmed that demand for farm products is a positive factor that encourages sales in short supply chains. In turn, in the opinion of $16 \%$ of breeders this factor hinders the possibility of entering into short supply chains and, according to more than $22 \%$, is a neutral element (Figure 1). Farms keeping particular animal species (Table 2) differed significantly in the assessment of this factor $\left(\chi^{2}=24.331, p=0.000\right)$. The highest rate of responses assessing it positively, as an encouraging factor, was noted among farms with cattle breeding $(82.4 \%)$, while among sheep farms it was about $51 \%$, and among those keeping pigs, $47 \%$. In the case of the latter type of farms, the highest percentage of responses $(36.8 \%)$ indicated that demand for farm products is a factor hindering the development of food sales in short supply chains. The location of farms (Table 3) also affected the differences in the identification of this factor $\left(\chi^{2}=18.731, p=0.001\right)$. The highest percentage of breeders who consider the demand for farm products as a factor encouraging to enter short food supply chains was recorded in Małopolskie Province (78.7\%). In the other two provinces it oscillated at over 57\% (Podkarpackie Province) and more than 53\% (Lubelskie Province). At the same time, among farms from the Lubelskie Province, the highest percentage of responses (28.9\%) indicated that the demand for farm products is a factor which negatively affects the decision on the production and sales of products in short supply chains.

The integration ties between farms and the market play an important role, because the development of farms depends on their maturity. This concerns, among others, acquiring information, using the knowledge of specialists, further education, and cooperation with other producers or institutions of the agricultural environment (Gołębiewska, 2010). Moreover, cooperation between local partners serves to strengthen their market position and is the key to success in the creation and durability of their business (Matysik-Pejas, 2020). There is another dimension of integration with the local market, which takes place in local farmers markets and 'bazaars'. These are places where a kind of relationship and social interaction takes place between trade participants, i.e. sellers and consumers. This helps to create public trust in entrepreneurs and greater goodwill for their business. The results of the conducted research show that the degree of integration with the local market was considered by the highest percentage of farms $(45.1 \%)$ as a neutral factor, and only about $30 \%$ of the surveyed farms regarded it as a favourable reason for making the decision to produce and sell products in short supply chains (Figure1). Verification 
of the results using the $\chi^{2}$ test showed differences in the perception of the importance of integration with the local market depending on the location of the farms $\left(\chi^{2}=19.992, p=0.001\right)$, see Table 3 . More than $40 \%$ of breeders from the Lubelskie Province, $34 \%$ from the Małopolskie Province and less than 18\% of breeders from the Podkarpackie Province considered integration with the local market as a factor positively determining their decision to enter into short supply chains.

Table 2. Relationship between the perception of factors determining the production and sale of products obtained from animals of native breeds by farms in short food supply chains and the species of animals kept on the farm

\begin{tabular}{|l|c|c|c|}
\hline \multirow{2}{*}{\multicolumn{1}{|c|}{ Factors }} & \multicolumn{2}{c|}{ Animal species $(\mathrm{df}=4)$} & \multirow{2}{*}{$\begin{array}{c}\text { Adopted } \\
\text { hypothesis }\end{array}$} \\
\cline { 2 - 3 } & $p$-value & $\chi^{2}$ & $\mathrm{H}_{1}$ \\
\hline Knowledge and skills & 0.000 & 23.939 & $\mathrm{H}_{1}$ \\
\hline Demand for farm products & 0.000 & 24.331 & $\mathrm{H}_{0}$ \\
\hline Degree of integration with the local market & 0.469 & 9.831 & $\mathrm{H}_{0}$ \\
\hline Own work input & 0.265 & 5.131 & $\mathrm{H}_{0}$ \\
\hline Development of marketing concept for the business & 0.127 & 7.171 & $\mathrm{H}_{0}$ \\
\hline Tax regulations & 0.102 & 7.719 & $\mathrm{H}_{0}$ \\
\hline Veterinary and sanitary regulations & 0.452 & 3.675 & \multicolumn{2}{c}{} \\
\hline
\end{tabular}

Source: own research.

Table 3. Relationship between the perception of factors determining the production and sale of products obtained from animals of native breeds by farms in short food supply chains and the location of farms

\begin{tabular}{|l|c|c|c|}
\hline \multirow{2}{*}{\multicolumn{1}{|c|}{ Factors }} & \multicolumn{2}{c|}{ Province $(\mathrm{df}=4)$} & \multirow{2}{*}{$\begin{array}{c}\text { Adopted } \\
\text { hypothesis }\end{array}$} \\
\cline { 2 - 4 } & $p$-value & $\chi^{2}$ & $\mathrm{H}_{0}$ \\
\hline Knowledge and skills & 0.058 & 9.123 & $\mathrm{H}_{1}$ \\
\hline Demand for farm products & 0.001 & 18.731 & $\mathrm{H}_{1}$ \\
\hline Degree of integration with the local market & 0.001 & 19.992 & $\mathrm{H}_{1}$ \\
\hline Own work input & 0.003 & 18.864 & $\mathrm{H}_{0}$ \\
\hline Development of marketing concept for the business & 0.414 & 3.936 & $\mathrm{H}_{0}$ \\
\hline Tax regulations & 0.584 & 2.847 & $\mathrm{H}_{0}$ \\
\hline Veterinary and sanitary regulations & 0.078 & 8.397 & \multicolumn{2}{|c}{} \\
\hline
\end{tabular}

Source: own research.

Running farms focused on animal production is associated with specific work inputs, usually higher than in the case of plant production (Kocira and Malaga-Taboła, 2012). Work inputs are also varied depending on the species of animals kept on the farm. In the described farms, the highest input was recorded in farms specializing in pig breeding (which results from the specificity of livestock production), while the 
lowest was observed in sheep farms (Borecka, Cieślik, Matysik-Pejas, DomagalskaGrędys, Sowula-Skrzyńska, and Żmija, 2019). The situation of individual farms in terms of labour resources may not be conducive to the development of additional activity, in particular fairly labour-intensive, because connected with the processing of raw materials, sales of products and sales-related activities. The obtained results indicate that over $62 \%$ of breeders considered their own labor input as a factor hindering the decision to enter short supply chains. Only about $13 \%$ of breeders were of a different opinion, and less than $25 \%$ considered this factor to be neutral (Figure 1). The analysis using the $\chi^{2}$ test confirmed the existence of statistical differences in the assessment of this factor by farms depending on their location $\left(\chi^{2}=18.864, p=0.003\right)$, see Table 3 . The highest percentage of indications of own work input as a factor hindering the decision to expand the business by selling in short supply chains, was obtained among farms in the Lubelskie Province and was almost $77 \%$. In the Małopolskie Province this indicator was about $70 \%$, while in the Podkarpackie Province it was less than $45 \%$. In the latter province, $40 \%$ of the surveyed farms indicated their own work input as a neutral factor, while in the other two provinces this percentage was at the level of around $12 \%-13 \%$.

The sales of products in short food supply chains requires farms to develop a certain marketing concept for this activity and to create an appropriate market image. In the case of farms keeping native breeds of animals, the marketing concept should focus on aspects related to the offered products. They must be its main angle, because raw materials obtained from native breeds, fed in a traditional way, are characterized by a high content of biologically active substances that positively affect human health (Barłowska, 2011). Products made from such raw materials, often according to traditional, home-made recipes, have specific characteristics and taste attributes that should be particularly emphasized. Furthermore, these are products of known origin. Farms can also use the logo "Polish Native Breed", to promote products of a specific Polish breed kept in natural breeding and feeding systems (Krupiński, Radomski, Moskała, Mikosz, and Paleczny, 2017, pp. 210-211). Participation in short supply chains is also an opportunity for farmers to set a higher price than when selling raw materials. This is the result of adding value to food by preparing it for sale on the farm (Kania and Musiał, 2017). A higher price will be accepted by those consumers who are willing to pay for locally produced food (Gilg and Battershill, 1998). Farms also need to choose the right way to reach consumers in local markets, i.e. decide on the form of short supply chain and place of sale. This allows farmers to offer their products on the farm, but also outside the farm, using local farmers market or home delivery. They can also sell their products to local restaurants and shops. This also gives farmers the opportunity to participate in local events such as exhibitions, festivals and trade fairs organized to promote local food Which, however, is a completely new approach to the market for farms that only sell raw materials derived from animal production. Therefore, about $60 \%$ of owners considered the factor which is the development of a marketing concept as a barrier to the decision to sell products directly to consumers. In turn, less than $30 \%$ of the respondents indicated that this is a neutral factor, and about 
$11 \%$ agreed that it is an encouraging factor to sell in short supply chains (Figure 1). The analysis of the results using the $\chi^{2}$ test did not confirm the existence of statistical differences in the assessment of this factor by farms (Tables 2 and 3).

To protect the health and life of consumers and their economic interests, the sale of products of animal origin in short supply chains must be regulated by specific legal, veterinary, sanitary and tax rules. Direct sales, marginal, local and limited activity (MLO) and agricultural retail trade (RHD) are defined by a number of documents, the fulfilment of which allows small agricultural producers to process and sell products directly to consumers. They may seem quite complicated to farmers, which they expressed by indicating these regulations as a factor hindering the functioning of farms in short food supply chains (almost $85 \%$ of indications). Only $1.4 \%$ of farms regarded these regulations to be encouraging and about $14 \%$ to be neutral determinants of their decision to produce and sell products derived from native breeds of animals in short food supply chains (Figure 1). The analysis of the results using the $\chi^{2}$ test did not confirm the existence of statistical differences in the evaluation of this factor by the farms (Tables 2 and 3).

\section{Conclusion}

In recent years the popularity of short food supply chains has been increasing. Their creation favours interaction and ties between agricultural producers and consumers. Short supply chains can also allow for the revival and development of local traditional processing and create local markets. These channels often offer food products of specific quality resulting from the unique traditional methods of their production.

The production of food with special characteristics on farms keeping animals of native breeds can be a source of additional income. This is important in the context of the fact that the production carried out on these farms is generally inefficient. Therefore, farms with animals of native breeds should take advantage of the opportunities offered by short supply chains. Yet among the surveyed farms, production and sales of products in short food supply chains were carried out on a very small scale. This shows that decisions about such activity are not easy because they require solving many issues. There exist factors that stimulate these processes and those that constitute barriers for them. In the opinion of farm owners, the group of determinants positively stimulating the development of this activity includes the knowledge and skills of breeders and the expected demand for products from the farms. In turn, the group of factors constituting barriers and causing farms not to undertake activities connected with short food supply chains is related to the necessary own work input, the need to develop a marketing concept for this activity and create an appropriate image on the market, as well as veterinary, sanitary and tax regulations.

Short food supply chains are very valuable initiatives not only for the farmers. Due to the direct relationship between the producer and consumers in these chains, consumer awareness and knowledge about products, their origin and production methods are being increased. 


\section{References}

Aguiar, L. C., DelGrossi, M. E., and Thomé, K. M. (2018). Short food supply chain: Characteristics of a family farm. Ciência Rural, 48(5), 1-8.

Barłowska, J. (2011). Znaczenie lokalnych ras zwierząt w produkcji żywności tradycyjnej oraz przekazie tradycji i kultury regionu. Przeglad Hodowlany, 9(79), 4-8.

Borecka, A., Cieślik, J., Matysik-Pejas, R., Domagalska-Grędys, M., Sowula-Skrzyńska, E., and Żmija, J. (2019). Uwarunkowania ekonomicznego rozwoju gospodarstw rodzinnych utrzymujacych zwierzęta gospodarskie ras zachowawczych w powiązaniu z otoczeniem rynkowym, Kraków: Wydawnictwo Uniwersytetu Rolniczego im. Hugona Kołłątaja w Krakowie.

Born, H., and Bachmann, J. (2006). Adding Value to Farm Products: An Overview. Appropriate Technology Transfer for Rural Areas - National Center for Appropriate Technology. Retrieved from https://attra.ncat.org/attra-pub/summaries/summary.php?pub=270

Derehajło, B. (2018). Zarządzanie gospodarstwem rolnym w warunkach gospodarki rynkowej. In E., Czernyszewicz, and E. Kołodziej (Eds.), Jakość i zarządzanie w agrobiznesie. Wybrane aspekty, Lublin: Katedra Zarządzania i Marketingu, Wydział Agrobioinżynierii, Uniwersytet Przyrodniczy w Lublinie.

Elghannam, A., Mesias, F. J., Escribano, M., Fouad, L., Horrillo, A., and Escribano, A. J. (2019). Consumers' Perspectives on Alternative Short Food Supply Chains Based on Social Media: A Focus Group Study in Spain. Foods, 9(22), 1-13.

Galli, F., and Brunori, G. (eds.). (2013). Short food supply chains as drivers of sustainable development. Evidence document (Document developed in the framework of the FP7 project Foodlinks (GA No. 265287)). Retrieved from https://orgprints.org/28858/1/evidence-document-sfsc-cop.pdf

Gilg, A. W., and Battershill, M. (1998). Quality farm food in Europe: A possible alternative to the industrialised food market and to current agri-environmental policies: Lessons from France. Food Policy, 23(1), 25-40.

Gołębiewska, B. (2010). Organizacyjno-ekonomiczne skutki zróżnicowania powiązań gospodarstw rolniczych z otoczeniem. Rozprawy Naukowe i Monografie. Warszawa: Wydawnictwo SGGW.

Gołębiewski, J. (2019). Systemy żywnościowe w warunkach gospodarki cyrkularnej. Studium porównawcze krajów Unii Europejskiej. Warszawa: Wydawnictwo SGGW.

Herda-Kopańska, J. (2017). Efekty mnożnikowe w rolnictwie. Roczniki Naukowe Stowarzyszenia Ekonomistów Rolnictwa i Agrobiznesu, XIX, (3), 79-84.

Kania, J., and Musiał, W. (2017). Dodawanie wartości w łańcuchach dostaw żywności - studium przypadku. Roczniki Naukowe Stowarzyszenia Ekonomistów Rolnictwa i Agrobiznesu, XIX, (6), 105-110.

Kneafsey, M., Venn, L., Schmutz, U., Balázs, B., Trenchard, L., Eyden-Wood, T., Bos, E., Sutton, G., and Blackett, M. (2013). Short food supply chains and local food systems in the EU. The state of play of their socio-economic characteristics. European Commission, Brussels, Belgium.

Kocira, S., and Malaga-Taboła, U. (2012). Zasoby i nakłady pracy ludzkiej w gospodarstwach o różnym kierunku produkcji. Problemy Inżynierii Rolniczej, 2(76), 27-36.

Krupiński, J. (ed.). (2012). Polskie rasy zachowawcze. Atlas zwierząt gospodarskich objętych programem ochrony w Polsce. Kraków: Instytut Zootechniki Państwowy Instytut Badawczy.

Krupiński, J., Radomski, P., Moskała, P., Mikosz, P. M., and Paleczny, K. (2017). Certyfikacja surowców i produktów ras rodzimych. Wiadomości Zootechniczne, LV, (5), 210-218.

La Trobe, H. (2001). Farmers' markets: Consuming local rural produce. International Journal of Consumer Studies, 25(3), 181-192.

Marketing sustainable agriculture: Case Studies and Analysis from Europe. (1998). Institute for Agriculture and Trade Policy, USA. Retrieved from http://www.iatp.org/files/Marketing_Sustainable_ Agriculture_-_Case_Studi.pdf

Matysik-Pejas, R. (2020). Short food supply chains and their impact on improving farm performance as perceived by farmers keeping native breeds. Annals of The Polish Association of Agricultural and Agribusiness, XXII, (1), 232-240. 
Michalczyk, J. (2017). Znaczenie lokalnej żywności oraz krótkich łańcuchów dostaw w kształtowaniu zrównoważonego rozwoju rolnictwa i obszarów wiejskich w Unii Europejskiej. Ekonomia Międzynarodowa, (17), 5-20.

Michalczyk, J. (2018). Zrównoważone łańcuchy dostaw żywności. Wybrane inicjatywy. Prace Naukowe Uniwersytetu Ekonomicznego we Wrocławiu, (523), 221-241.

Mount, Ph. (2012). Growing local food, scale and local food systems governance. Agriculture and Human Values, 29(1), 107-121.

Serafin, R. (2018). Bariery i szanse dla rozwoju systemów KŁŻ dla potrzeb Kampanii , Wiedz i Mądrze Jedz” (Ekspertyza zrealizowana w ramach operacji pt. Ogólnopolska kampania na rzecz krótkich łańcuchów dostaw żywności). Retrieved from http://faow.org.pl/wp-content/uploads/2018/12/4-BarierySzanse_15102018.pdf

Official Journal of the European Union, 2018/C 129/04.

Official Journal of the European Union, 2011/C 104/01.

Peters, R. (Ed.). (2012). Local food and short supply chains. EU Rural Review. 12. Retrieved from https://enrd.ec.europa.eu/sites/enrd/files/E8F24E08-0A45-F272-33FB-A6309E3AD601.pdf

Pinchot, A. (2014). The economics of local food systems: A literature review of the production, distribution, and consumption of local food. University of Minnesota, Extension Center for Community Vitality.

Short food supply chains in Europe's North. (2018a). (Special report, 25-29 June, 2018). Retrieved from https://en.euractiv.eu/wp-content/uploads/sites/2/special-report/EA-SPECIAL-REPORTDGAGRI-EN-03072018.pdf

Short food supply chains in Europe's South. (2018b). (Special report, 19-27 December, 2018). Retrieved from https://en.euractiv.eu/wp-content/uploads/sites/2/special-report/EURACTIV-Special-Report-Short-food-supply-chains-in-Europe $\% \mathrm{E} 2 \% 80 \% 99 \mathrm{~s}$-south.pdf

Sroka, W., Wojewodzic, T., and Pölling, B. (2016). Strategie i czynniki sukcesu gospodarstw rolnych w wybranych obszarach podmiejskich Europy. Roczniki Naukowe Ekonomii Rolnictwa i Rozwoju Obszarów Wiejskich, 103(2), 55-68.

Urban, S. (2008). Zarządzanie wiedzą w gospodarstwach rolnych. Polskie Stowarzyszenie Zarzadzania Wiedza, Seria: Studia i Materialy, (14), 142-149.

\section{WYBRANE UWARUNKOWANIA PRODUKCJI I SPRZEDAŻY TOWARÓW W KRÓTKIM LAŃCUCHU DOSTAW ŻYWNOŚCI PRZEZ GOSPODARSTWA ZAJMUJĄCE SIĘ HODOWLĄ ZWIERZĄT RAS RODZIMYCH}

Streszczenie: Celem badań była identyfikacja czynników determinujących podejmowanie przez gospodarstwa decyzji o wytwarzaniu i sprzedaży produktów pozyskanych ze zwierząt ras rodzimych w krótkich łańcuchach dostaw żywności. Materiał empiryczny stanowiły wyniki badań przeprowadzonych w 2017 r., w których wykorzystano metodę wywiadu bezpośredniego. Próba objęła 144 gospodarstwa utrzymujące zwierzęta ras rodzimych, takich jak bydło, owce i świnie. Zakres przestrzenny badań obejmował trzy województwa Polski południowo-wschodniej. Do czynników pozytywnie stymulujących rozwój sprzedaży żywności w krótkich łańcuchach dostaw należą posiadana przez hodowców wiedza i umiejętności oraz popyt na produkty pochodzące z gospodarstw. Do grupy czynników powodujących, że gospodarstwa nie podejmują tej działalności, zaliczono nakłady pracy własnej, potrzebę opracowania koncepcji marketingowej dla tej działalności i wykreowanie odpowiedniego wizerunku na rynku, a także przepisy weterynaryjne, sanitarne oraz podatkowe.

Słowa kluczowe: krótkie łańcuchy dostaw żywności, żywność pochodzenia zwierzęcego, rasy rodzime. 